\title{
Modelling of Asphalt Pavement Structures for Different Design Conditions on Roads in Northern Colombia
}

\author{
Fernando Jove Wilches*1, Giancarlo Patrón Lambraño ${ }^{2}$ and Carlos Millán-Páramo ${ }^{1}$ \\ ${ }^{1}$ Department of Civil Engineering, Universidad de Sucre, Sincelejo, Sucre, Colombia. \\ ${ }^{2}$ Faculty of Engineering, Universidad Tecnológica de Bolivar, Turbaco, Colombia.
}

ORCIDs: 0000-0002-2080-4036 (Fernando), 0000-0002-1044-8648 (Giancarlo), 0000-0002-0004-6063 (Carlos)

\begin{abstract}
The purpose of this manuscript is to present a collection of data showing the different variables involved in the design of asphalt pavements, obtained from 84 road sectors located in urban and rural roads in the department of Sucre, north of Colombia. The dataset presents the results of geotechnical studies obtained from soil samples taken in the field and from laboratory tests. Among the most relevant information, the characterization of the subgrade soils was determined, based on particle size analysis testing, Atterberg limits, natural moisture and the classification of soils based in the AASHTO system and the USCS system. The bearing capacity of the subgrade is also presented, from undisturbed samples, for the realization of the laboratory California Bearing Ratio. On the other hand, there is information related to design traffic for each of the evaluated road sectors, expressed in terms of the number of equivalent single axle loads (ESALs). Finally, the information was supplemented with the results of the pavement structures modeled and chosen as design alternatives, for which a rational design methodology was used and the fatigue laws of the TRRL (Transport and Road Research Laboratory) were followed, making use of the Pitra PAVE software to model pavement structures.
\end{abstract}

Keywords: Soil characterization, subgrade, pavement design, rational methodology, flexible pavements

\section{INTRODUCTION}

The main objective sought in the design of a pavement is to provide alternative structures that are feasible to implement, from a technical, economic and environmental point of view, and that allow optimizing the level of service offered to users [1]. For this purpose, it is necessary to combine the thicknesses of the layers and the qualities of their constituent materials, in such a way that they adjust to the anticipated conditions of traffic and environment, maintaining reasonable costs both in the construction phase and in the operation construction phase[1].

With regard to flexible pavement structures, these are made up of an asphalt layer generally supported on two non-rigid layers of base and granular sub-base, or one of these two intermediate layers, or both, can be dispensed with, depending on the particular needs of the project [2].
To carry out a good design, the different variables that directly affect its structural performance must be adequately characterized, such as traffic, subgrade, climate, mechanical properties of materials, as well as safety factors [3].

For the purposes of the structural analysis of a pavement, the traffic variable is considered one of the most relevant [2] and in the case of flexible pavement, it is represented through the number of equivalent single axle loads of 8.2 tons expected in the design lane during the design period [4]. In the case of the subgrade or support layer of the pavement, it is characterized through the resilient module; However, due to the limited availability of equipment required to carry out these tests and the high cost they represent, in Colombia it is generally accepted to determine the modulus based on the characteristic CBR of the subgrade soils of the design unit, from of recognized correlations [5].

In this work, 84 combinations of flexible pavement structures are proposed, taking as a reference for structural modeling purposes, different levels of traffic, subgrade support capacity and combination of structural layers. Regarding traffic, seven levels were considered, representative of different numbers of repetitions of equivalent standard axles: 50,000, 100,000, $150,000,200,000,300,000,400,000$ and 500,000. In the case of the subgrade, we worked with three levels of resilient modulus: 300,400 and $500 \mathrm{~kg} / \mathrm{cm}^{2}$, and with regard to the layers used, we worked with four combinations: structure 1, is composed of layers of Asphalt Concrete (AC), Granular Base (GB) and Granular Subbase (GSB); Structure 2 is made up of Asphalt Concrete and Granular Base; Structure 3, composed of Asphalt Concrete and Granular Subbase and, Structure 4, is only composed of the Asphalt Concrete layer. In Figure 1 the location of the study area is presented.

\section{EXPERIMENTAL DESIGN, MATERIALS AND METHODS}

\section{II.I Study area description}

The territory of the department of Sucre is located in the north of Colombia, in the intermediate part of the region of the Caribbean Plain and has an area of $10,917 \mathrm{~km} 2$. A little more than a third of its territory forms the flood-prone depression of the Bajo Magdalena, Cauca and San Jorge rivers, characterized by numerous swamps, especially along the San Jorge River. Its 
International Journal of Engineering Research and Technology. ISSN 0974-3154, Volume 13, Number 11 (2020), pp. $3934-3942$

(C) International Research Publication House. https://dx.doi.org/10.37624/IJERT/13.11.2020.3934-3942

location extends in North latitude between $10^{\circ} 08$ '03 "in the vicinity of the Pueblo Nuevo site and the Caño Sangre de Toro (municipality of San Onofre), corresponding to the most extreme North point and $08^{\circ} 16^{\prime} 46^{\prime \prime}$ in the site of concurrence with the Córdoba and Bolívar departments, corresponding to the most extreme South point. In west longitude, it extends between $7^{\circ} 32^{\prime} 35^{\prime \prime}$ on the banks of the Cauca River and near the municipal seat of Guaranda, and $75^{\circ} 42^{\prime} 25^{\prime \prime}$ at San Bernardo point, to the west (municipality of San Onofre). The department of Sucre borders on the North and East with the department of Bolívar; to the south, with the departments of Bolívar and Córdoba, and to the west, with the department of Córdoba and the Caribbean Sea, show in Fig. 1. The departmental boundary perimeter has an approximate length of $671 \mathrm{~km}$, which are discriminated as follows: 100 kilometres with the Caribbean Sea, equivalent to $14.9 \%$ of the total perimeter; 345 kilometres with the department of Córdoba, equivalent to $51.4 \%$ of the total perimeter, and 226 kilometres with the department of Bolívar, equivalent to $33.7 \%$ of the total departmental perimeter. The department of Sucre is made up of five subregions, which are the following: Morrosquillo, Montes de María, Sabanas, Mojana and San Jorge Subregions [6], [7].

The location of the study area is shown in Figure 1.

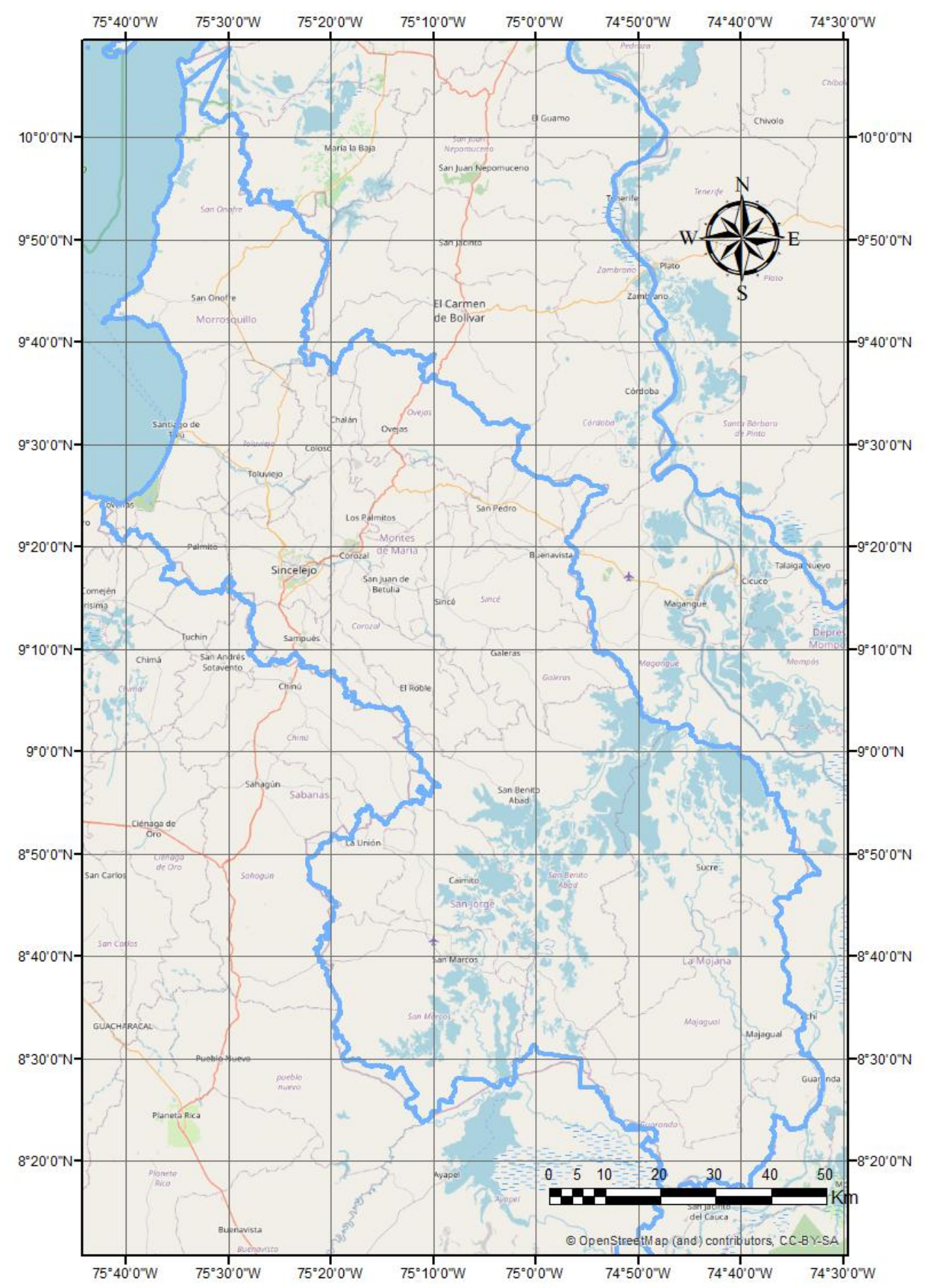

Fig. 1. Location of department of Sucre (research zone). 


\section{II.II Material and Methods}

The information collected that served as input for the preparation of this work corresponds to the results of geotechnical road investigations, various levels of design traffic and modeling for the design of asphalt pavement structures. From the geotechnical studies, soil samples were collected from geotechnical surveys carried out in various sectors of roads in the department of Sucre. Then they were analyzed in the laboratory, using for this purpose standard soil analysis methods. From the characterization of the subgrade soils and various levels of traffic, different design alternatives were obtained in asphalt pavement structure. For the structural modeling of pavements, a rational methodology and the TRRL fatigue laws were used. To determine the state of stresses and deformation generated in the models, the Pitra PAVE Software was used.

The input data used in the modeling correspond to the characterization and bearing capacity properties of the subgrade soils, to the design traffic values obtained from the characterization of the vehicular flows of the evaluated road sectors and to the properties of the materials that make up the pavement structures considered. For the characterization of the soils, samples were taken at different sites located along the road corridors under study. The samples were transported to the laboratory, to carry out tests and analysis to determine some physical and mechanical properties, for which, standard soil laboratory methods were used. The tests carried out consisted in the determination of the granulometry, the natural moisture, the Atterberg limits and the California Bearing Ratio (CBR). The design traffic data correspond to the number of equivalent single axle loads (ESALs), determined from field measurements of the number of heavy vehicles that travel on the roads, and their projection through a design period of 10 years, applying the ASTHOO methodology, through the law of the fourth power. The data of flexible pavement designs were obtained based on the bearing capacity of the subgrade, the design traffic and the mechanical characteristics of the materials of the different layers of the structure, applying for this purpose, mechanistic analysis using the Pitra PAVE software and TRRL fatigue laws.

Regarding the geotechnical characterization, a total of 84 representative samples of clay subgrade soils were taken along various road sectors located in different sites in the department of Sucre, in order to establish their physical and mechanical properties through standardized laboratory tests. Each geotechnical survey carried out was carried out manually and extended to a depth of 1.50 meters with respect to the existing surface, and in each one, both altered and undisturbed samples were taken. The altered samples collected were processed in the laboratory to obtain information related to the particle size analysis of soils, by sieving [8] and the Atterberg limits, using the Casagrande pan, in the case of the liquid limit, and the realization of rolls manually, in the case of the plastic limit [9], in order to determine the classification of soils through the Unified Soil Classification System (USCS) [10] and the AASHTO Soil Classification System [11]. The unaltered samples were taken through standardized cylindrical molds, in order to carry out the laboratory test of the California Bearing Ratio (CBR) [12], for which, the samples were previously subjected to a curing process by immersion during a four day period. Prior to the time of submerging the samples for CBR, the natural humidity was determined and their respective wet and dry unit weights were calculated for each CBR mold.

For the characterization of the materials of the pavement structure, it proceeded as follows: for the case of the hot asphalt mix, a dynamic modulus value representative of the particular conditions of the mixes used in the area of project and regarding the granular layers, we worked with the correlations established by the design methodology for flexible pavements of the AASHTO [13], based on the CBR values required by the technical specifications of the Instituto Nacional de Vias (INVIAS) of Colombia [14], for the case of sub-bases and granular bases. Regarding the Poisson's ratios, the values recommended in the document "Investigation of performance of subbase and subgrade and design guidelines for concrete pavement" [15] were taken.

With regard to traffic, vehicle gauges were made and based on these results and considering the damage factors obtained in previous studies carried out by the INVIAS, the design traffic could be obtained in terms of the number of standard axles equivalents expected in the design lane for a design period of 10 years. For modeling purposes, seven traffic categories were considered, ranging between 50,000 and 500,000 repetitions of equivalent standard axles, a range that encompasses different levels of vehicle heavy traffic for roads considered with low volumes of traffic, which are nevertheless of utmost importance, since they allow land communication between the agricultural and livestock production centers with the departmental capitals.

Once the design parameters were defined for each case, the structure was modeled, with the traffic input data, the mechanical characteristics of the structure's materials and the bearing capacity of the subgrade. For this purpose, a rational methodology was used to obtain the critical stresses and strains and the TRRL fatigue laws, to determine the number of admissible repetitions, in such a way that it was possible to define the combination of thickness of layers that will provide a satisfactory solution.

\section{RESULTS}

For the modeling of the structures obtained, the fatigue laws proposed by the TRRL of Great Britain were used, through Equations 1 and 2, which allowed obtaining the admissible repetition values for the two deterioration criteria considered for purposes of design, which are related to the fatigue cracking in the asphalt layers and the permanent deformation of the subgrade, respectively.

$N_{f}=f_{1} \varepsilon_{t}-f_{2}$

Where:

$\mathrm{Nf}=$ Number of admissible repetitions, for the criterion of maximum stress deformation in asphalt layers.

$\mathrm{f} 1=1.66 \times 10^{-10} \mathrm{f} 2=4.32$ 
International Journal of Engineering Research and Technology. ISSN 0974-3154, Volume 13, Number 11 (2020), pp. 3934-3942 (C) International Research Publication House. https://dx.doi.org/10.37624/IJERT/13.11.2020.3934-3942

$N_{d}=f_{4} \varepsilon_{c}-f_{5}$

Where:

$\mathrm{Nd}=$ Number of admissible repetitions, for the criterion of maximum compression deformation on the subgrade. $\mathrm{f} 4=6.18 \times 10^{-8} \quad \mathrm{f} 5=3.97$

Table 1 shows the summary of the characterization of the subgrade soils, the admissible traffic flows and the thickness of the layers of the pavement structures obtained from the modeling.

Table 1. Summary of subgrade soils, vehicular flows and flexible pavement structures.

\begin{tabular}{|c|c|c|c|c|c|c|c|}
\hline \multirow[b]{2}{*}{$\begin{array}{c}\text { Road } \\
\text { Section }\end{array}$} & \multirow[b]{2}{*}{$\begin{array}{c}\text { Design } \\
\text { Traffic } \\
\text { (ESALs) }\end{array}$} & \multirow[b]{2}{*}{$\begin{array}{c}\text { Improvement } \\
\text { Module }\left(\mathrm{kg} / \mathrm{cm}^{2}\right)\end{array}$} & \multirow[b]{2}{*}{$\begin{array}{l}\text { Pavement } \\
\text { Solution }\end{array}$} & \multicolumn{3}{|c|}{ Pavement Structure Layers (mm) } & \multirow[b]{2}{*}{$\begin{array}{c}\text { Sub-grade } \\
\text { Improvement } \\
\text { Layer }(\mathbf{m m})\end{array}$} \\
\hline & & & & $\begin{array}{c}\text { Asphalt } \\
\text { Concrete } \\
\text { (AC) }\end{array}$ & $\begin{array}{l}\text { Granular } \\
\text { Base (GB) }\end{array}$ & $\begin{array}{c}\text { Granular } \\
\text { Subbase } \\
\text { (GSB) }\end{array}$ & \\
\hline 1 & 100581 & 488 & $\mathrm{AC}+\mathrm{GB}+\mathrm{GSB}$ & 50 & 300 & 300 & 150 \\
\hline 2 & 412612 & 554 & $\mathrm{AC}+\mathrm{GB}+\mathrm{GSB}$ & 110 & 250 & 250 & 150 \\
\hline 3 & 554722 & 401 & $\mathrm{AC}+\mathrm{GB}$ & 120 & 350 & & 250 \\
\hline 4 & 101400 & 402 & $\mathrm{AC}+\mathrm{GSB}$ & 110 & & 350 & 250 \\
\hline 5 & 103264 & 422 & $\mathrm{AC}+\mathrm{GB}+\mathrm{GSB}$ & 50 & 300 & 300 & 250 \\
\hline 6 & 598768 & 297 & $\mathrm{AC}+\mathrm{GB}+\mathrm{GSB}$ & 130 & 200 & 250 & 200 \\
\hline 7 & 304167 & 393 & $\mathrm{AC}+\mathrm{GB}+\mathrm{GSB}$ & 100 & 250 & 250 & 200 \\
\hline 8 & 280606 & 528 & $\mathrm{AC}$ & 160 & & & 300 \\
\hline 9 & 154274 & 299 & $\mathrm{AC}$ & 160 & & & 350 \\
\hline 10 & 178190 & 333 & $\mathrm{AC}+\mathrm{GB}$ & 80 & 350 & & 300 \\
\hline 11 & 117483 & 316 & $\mathrm{AC}+\mathrm{GB}+\mathrm{GSB}$ & 70 & 200 & 200 & 250 \\
\hline 12 & 528094 & 300 & $\mathrm{AC}+\mathrm{GB}$ & 120 & 350 & & 250 \\
\hline 13 & 148911 & 430 & $\mathrm{AC}+\mathrm{GB}$ & 70 & 300 & & 300 \\
\hline 14 & 305832 & 309 & $\mathrm{AC}+\mathrm{GSB}$ & 140 & & 500 & 250 \\
\hline 15 & 201191 & 430 & $\mathrm{AC}+\mathrm{GB}$ & 80 & 450 & & 300 \\
\hline 16 & 150051 & 403 & $\mathrm{AC}$ & 150 & & & 300 \\
\hline 17 & 54340 & 411 & $\mathrm{AC}+\mathrm{GB}+\mathrm{GSB}$ & 50 & 150 & 150 & 250 \\
\hline 18 & 427355 & 300 & $\mathrm{AC}$ & 190 & & & 300 \\
\hline 19 & 231035 & 288 & $\mathrm{AC}+\mathrm{GB}$ & 90 & 350 & & 250 \\
\hline 20 & 214221 & 403 & $\mathrm{AC}$ & 160 & & & 300 \\
\hline 21 & 307872 & 325 & $\mathrm{AC}$ & 180 & & & 350 \\
\hline 22 & 54503 & 415 & $\mathrm{AC}+\mathrm{GB}$ & 50 & 250 & & 300 \\
\hline 24 & 107059 & 319 & $\mathrm{AC}$ & 150 & & & 400 \\
\hline 25 & 431400 & 517 & $\mathrm{AC}+\mathrm{GB}$ & 110 & 350 & & 250 \\
\hline 26 & 219303 & 299 & $\mathrm{AC}$ & 170 & & & 350 \\
\hline 27 & 50245 & 300 & $\mathrm{AC}+\mathrm{GSB}$ & 90 & & 400 & 250 \\
\hline 28 & 419737 & 309 & $\mathrm{AC}+\mathrm{GSB}$ & 150 & & 500 & 250 \\
\hline 29 & 101007 & 300 & $\mathrm{AC}+\mathrm{GSB}$ & 110 & & 400 & 250 \\
\hline 30 & 301713 & 403 & $\mathrm{AC}$ & 170 & & & 300 \\
\hline 31 & 199155 & 332 & $\mathrm{AC}+\mathrm{GB}+\mathrm{GSB}$ & 90 & 200 & 250 & 250 \\
\hline 32 & 153364 & 322 & $\mathrm{AC}+\mathrm{GB}+\mathrm{GSB}$ & 80 & 200 & 250 & 250 \\
\hline 33 & 52052 & 313 & $\mathrm{AC}+\mathrm{GB}+\mathrm{GSB}$ & 50 & 150 & 200 & 250 \\
\hline 34 & 392603 & 477 & $\mathrm{AC}$ & 180 & & & 250 \\
\hline
\end{tabular}


International Journal of Engineering Research and Technology. ISSN 0974-3154, Volume 13, Number 11 (2020), pp. 3934-3942 (C) International Research Publication House. https://dx.doi.org/10.37624/IJERT/13.11.2020.3934-3942

\begin{tabular}{|c|c|c|c|c|c|c|c|}
\hline \multirow[b]{2}{*}{$\begin{array}{c}\text { Road } \\
\text { Section }\end{array}$} & \multirow[b]{2}{*}{$\begin{array}{l}\text { Design } \\
\text { Traffic } \\
\text { (ESALs) }\end{array}$} & \multirow[b]{2}{*}{$\begin{array}{c}\text { Improvement } \\
\text { Module }\left(\mathrm{kg} / \mathrm{cm}^{2}\right)\end{array}$} & \multirow[b]{2}{*}{$\begin{array}{l}\text { Pavement } \\
\text { Solution }\end{array}$} & \multicolumn{3}{|c|}{ Pavement Structure Layers (mm) } & \multirow[b]{2}{*}{$\begin{array}{c}\text { Sub-grade } \\
\text { Improvement } \\
\text { Layer }(\mathbf{m m})\end{array}$} \\
\hline & & & & $\begin{array}{c}\text { Asphalt } \\
\text { Concrete } \\
\text { (AC) }\end{array}$ & $\begin{array}{l}\text { Granular } \\
\text { Base (GB) }\end{array}$ & $\begin{array}{c}\text { Granular } \\
\text { Subbase } \\
\text { (GSB) }\end{array}$ & \\
\hline 35 & 73151 & 310 & $\mathrm{AC}$ & 140 & & & 450 \\
\hline 36 & 56850 & 320 & $\mathrm{AC}+\mathrm{GB}$ & 70 & 250 & & 300 \\
\hline 37 & 150692 & 300 & $\mathrm{AC}+\mathrm{GSB}$ & 120 & & 450 & 250 \\
\hline 38 & 197751 & 305 & $\mathrm{AC}+\mathrm{GSB}$ & 130 & & 400 & 250 \\
\hline 39 & 313254 & 396 & $\mathrm{AC}+\mathrm{GB}$ & 100 & 350 & & 250 \\
\hline 40 & 149883 & 438 & $\mathrm{AC}+\mathrm{GB}+\mathrm{GSB}$ & 80 & 200 & 200 & 250 \\
\hline 41 & 303316 & 298 & $\mathrm{AC}+\mathrm{GB}$ & 100 & 350 & & 250 \\
\hline 42 & 212829 & 409 & $\mathrm{AC}+\mathrm{GSB}$ & 130 & & 400 & 250 \\
\hline 43 & 52312 & 522 & $\mathrm{AC}+\mathrm{GSB}$ & 90 & & 350 & 250 \\
\hline 44 & 206644 & 386 & $\mathrm{AC}+\mathrm{GB}+\mathrm{GSB}$ & 90 & 200 & 300 & 200 \\
\hline 45 & 542759 & 480 & $\mathrm{AC}$ & 180 & & & 250 \\
\hline 46 & 102099 & 522 & $\mathrm{AC}+\mathrm{GSB}$ & 110 & & 300 & 250 \\
\hline 47 & 577756 & 413 & $\mathrm{AC}$ & 190 & & & 300 \\
\hline 48 & 309974 & 409 & $\mathrm{AC}+\mathrm{GSB}$ & 140 & & 450 & 250 \\
\hline 49 & 301313 & 497 & $\mathrm{AC}+\mathrm{GSB}$ & 140 & & 350 & 200 \\
\hline 50 & 407302 & 409 & $\mathrm{AC}+\mathrm{GSB}$ & 150 & & 400 & 250 \\
\hline 51 & 406724 & 393 & $\mathrm{AC}+\mathrm{GB}+\mathrm{GSB}$ & 110 & 250 & 250 & 200 \\
\hline 52 & 200438 & 516 & $\mathrm{AC}+\mathrm{GB}$ & 80 & 450 & & 250 \\
\hline 53 & 70364 & 484 & $\mathrm{AC}+\mathrm{GB}+\mathrm{GSB}$ & 50 & 150 & 150 & 150 \\
\hline 54 & 94187 & 516 & $\mathrm{AC}$ & 130 & & & 300 \\
\hline 55 & 456391 & 290 & $\mathrm{AC}+\mathrm{GB}+\mathrm{GSB}$ & 120 & 200 & 250 & 200 \\
\hline 56 & 509404 & 309 & $\mathrm{AC}+\mathrm{GSB}$ & 160 & & 400 & 250 \\
\hline 57 & 70261 & 398 & $\mathrm{AC}$ & 130 & & & 300 \\
\hline 58 & 419804 & 403 & $\mathrm{AC}$ & 180 & & & 300 \\
\hline 59 & 519511 & 517 & $\mathrm{AC}+\mathrm{GB}$ & 120 & 250 & & 250 \\
\hline 60 & 542759 & 482 & $\mathrm{AC}$ & 180 & & & 250 \\
\hline 61 & 197909 & 524 & $\mathrm{AC}$ & 150 & & & 300 \\
\hline 62 & 524921 & 409 & $\mathrm{AC}+\mathrm{GSB}$ & 160 & & 350 & 250 \\
\hline 63 & 347256 & 332 & $\mathrm{AC}+\mathrm{GB}+\mathrm{GSB}$ & 110 & 200 & 250 & 250 \\
\hline 64 & 103537 & 401 & $\mathrm{AC}$ & 140 & & & 300 \\
\hline 65 & 82915 & 488 & $\mathrm{AC}+\mathrm{GB}$ & 50 & 250 & & 250 \\
\hline 66 & 307008 & 499 & $\mathrm{AC}+\mathrm{GB}+\mathrm{GSB}$ & 100 & 250 & 250 & 150 \\
\hline 67 & 416486 & 522 & $\mathrm{AC}+\mathrm{GSB}$ & 150 & & 350 & 200 \\
\hline 68 & 153326 & 526 & $\mathrm{AC}+\mathrm{GSB}$ & 120 & & 350 & 250 \\
\hline 69 & 508305 & 537 & $\mathrm{AC}+\mathrm{GSB}$ & 160 & & 250 & 200 \\
\hline 70 & 152652 & 510 & $\mathrm{AC}+\mathrm{GB}$ & 70 & 450 & & 250 \\
\hline 71 & 137600 & 522 & $\mathrm{AC}$ & 140 & & & 300 \\
\hline 72 & 151811 & 408 & $\mathrm{AC}+\mathrm{GSB}$ & 120 & & 400 & 250 \\
\hline 73 & 199448 & 497 & $\mathrm{AC}+\mathrm{GB}+\mathrm{GSB}$ & 90 & 200 & 200 & 150 \\
\hline
\end{tabular}




\begin{tabular}{|c|c|c|c|c|c|c|c|}
\hline \multirow[b]{2}{*}{$\begin{array}{c}\text { Road } \\
\text { Section }\end{array}$} & \multirow[b]{2}{*}{$\begin{array}{c}\text { Design } \\
\text { Traffic } \\
\text { (ESALs) }\end{array}$} & \multirow[b]{2}{*}{$\begin{array}{c}\text { Improvement } \\
\text { Module }\left(\mathrm{kg} / \mathrm{cm}^{2}\right)\end{array}$} & \multirow[b]{2}{*}{$\begin{array}{l}\text { Pavement } \\
\text { Solution }\end{array}$} & \multicolumn{3}{|c|}{ Pavement Structure Layers ( $\mathrm{mm})$} & \multirow[b]{2}{*}{$\begin{array}{c}\text { Sub-grade } \\
\text { Improvement } \\
\text { Layer }(\mathbf{m m})\end{array}$} \\
\hline & & & & $\begin{array}{c}\text { Asphalt } \\
\text { Concrete } \\
\text { (AC) }\end{array}$ & $\begin{array}{l}\text { Granular } \\
\text { Base (GB) }\end{array}$ & $\begin{array}{c}\text { Granular } \\
\text { Subbase } \\
\text { (GSB) }\end{array}$ & \\
\hline 74 & 97562 & 425 & $\mathrm{AC}+\mathrm{GB}$ & 50 & 300 & & 300 \\
\hline 75 & 541662 & 393 & $\mathrm{AC}+\mathrm{GB}+\mathrm{GSB}$ & 120 & 250 & 250 & 200 \\
\hline 76 & 204513 & 492 & $\mathrm{AC}+\mathrm{GSB}$ & 130 & & 300 & 200 \\
\hline 77 & 321716 & 516 & $\mathrm{AC}+\mathrm{GB}$ & 100 & 350 & & 250 \\
\hline 78 & 104098 & 495 & $\mathrm{AC}+\mathrm{GB}$ & 50 & 400 & & 250 \\
\hline 79 & 417279 & 396 & $\mathrm{AC}+\mathrm{GB}$ & 110 & 350 & & 250 \\
\hline 80 & 103784 & 331 & $\mathrm{AC}+\mathrm{GB}$ & 70 & 300 & & 300 \\
\hline 81 & 400687 & 298 & $\mathrm{AC}+\mathrm{GB}$ & 110 & 350 & & 250 \\
\hline 82 & 587138 & 311 & $\mathrm{AC}$ & 200 & & & 300 \\
\hline 83 & 151583 & 488 & $\mathrm{AC}+\mathrm{GB}+\mathrm{GSB}$ & 80 & 200 & 200 & 150 \\
\hline 84 & 552191 & 554 & $\mathrm{AC}+\mathrm{GB}+\mathrm{GSB}$ & 120 & 250 & 250 & 150 \\
\hline
\end{tabular}

The results of the alternative solutions for flexible pavement structures are shown in Fig. 2, Fig. 3, Fig. 4 and Fig. 5. In the figures, the abscissa axis shows the design transits in terms of ESALs, divided into categories of 50.000, 100.000, 150.000, 200.000, 300.000, 400.000 and 500.000. These values were selected taking into account the different traffic categories observed in the different evaluated road corridors. On the ordinate axis, the thicknesses of each layers of the pavement structures are shown, measured in millimeters. For the purposes of this article, 4 types of structures are presented: structure 1 , is composed of layers of Asphalt Concrete (AC), Granular Base (GB) and Granular Subbase (GSB), shown in Fig. 2; Structure 2 is made up of Asphalt Concrete and Granular Base (Fig. 3); Structure 3, composed of Asphalt Concrete and Granular Subbase (Fig. 4) and, Structure 4, is only composed of the Asphalt Concrete layer (Fig. 5). In a complementary way, for each traffic range, three pavement structures are presented, which are a function of the three different Improvement Module of the Sub-grade Improvement layer, which were 300, 400 and $500 \mathrm{~kg} / \mathrm{cm}^{2}$.

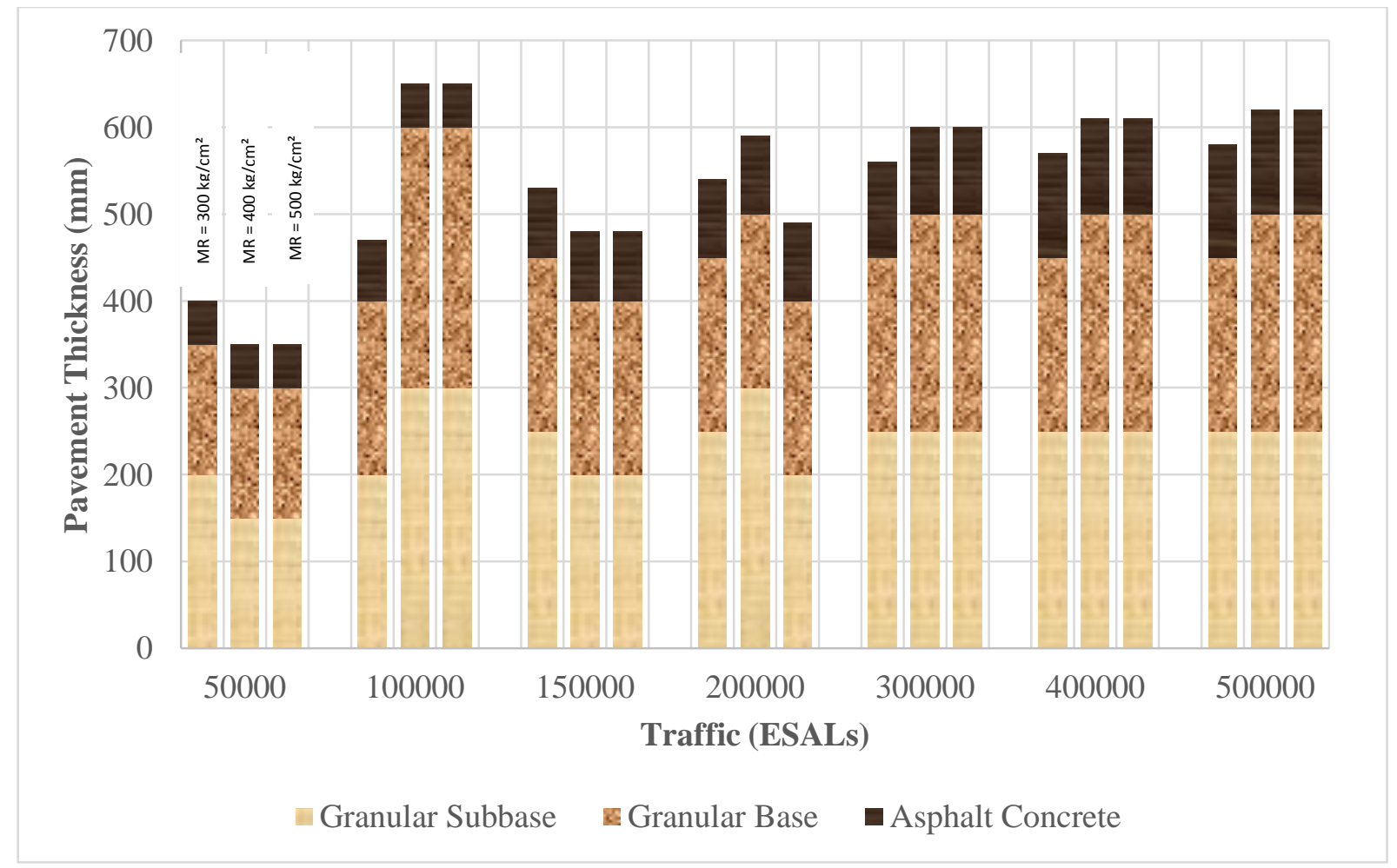

Fig. 2. Flexible pavement structures composed of AC, GB and GSB layers. 
International Journal of Engineering Research and Technology. ISSN 0974-3154, Volume 13, Number 11 (2020), pp. 3934-3942

○ International Research Publication House. https://dx.doi.org/10.37624/IJERT/13.11.2020.3934-3942

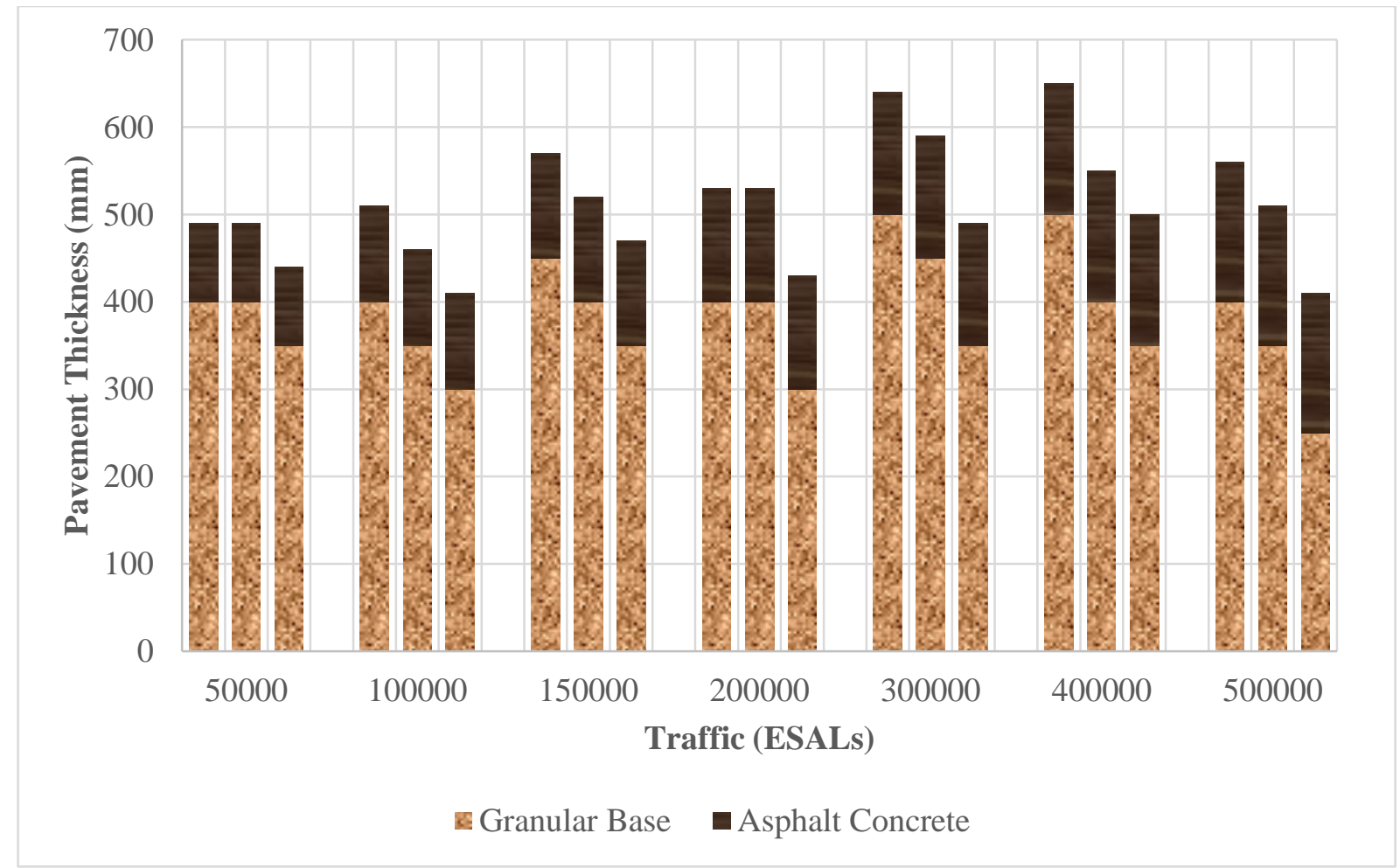

Fig. 3. Flexible pavement structures composed of AC and GB layers.

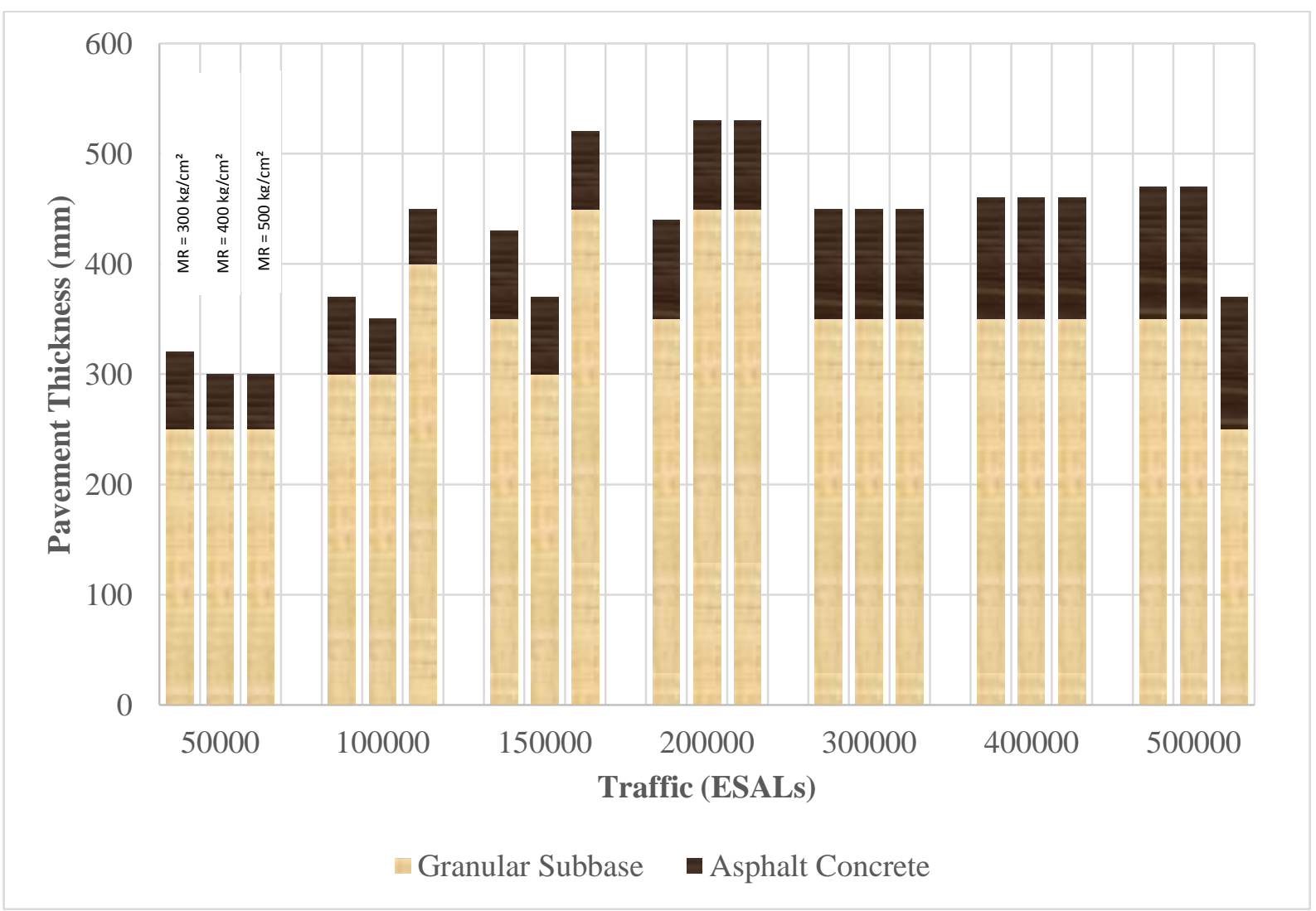

Fig. 4. Flexible pavement structures composed of AC and GSB layers. 


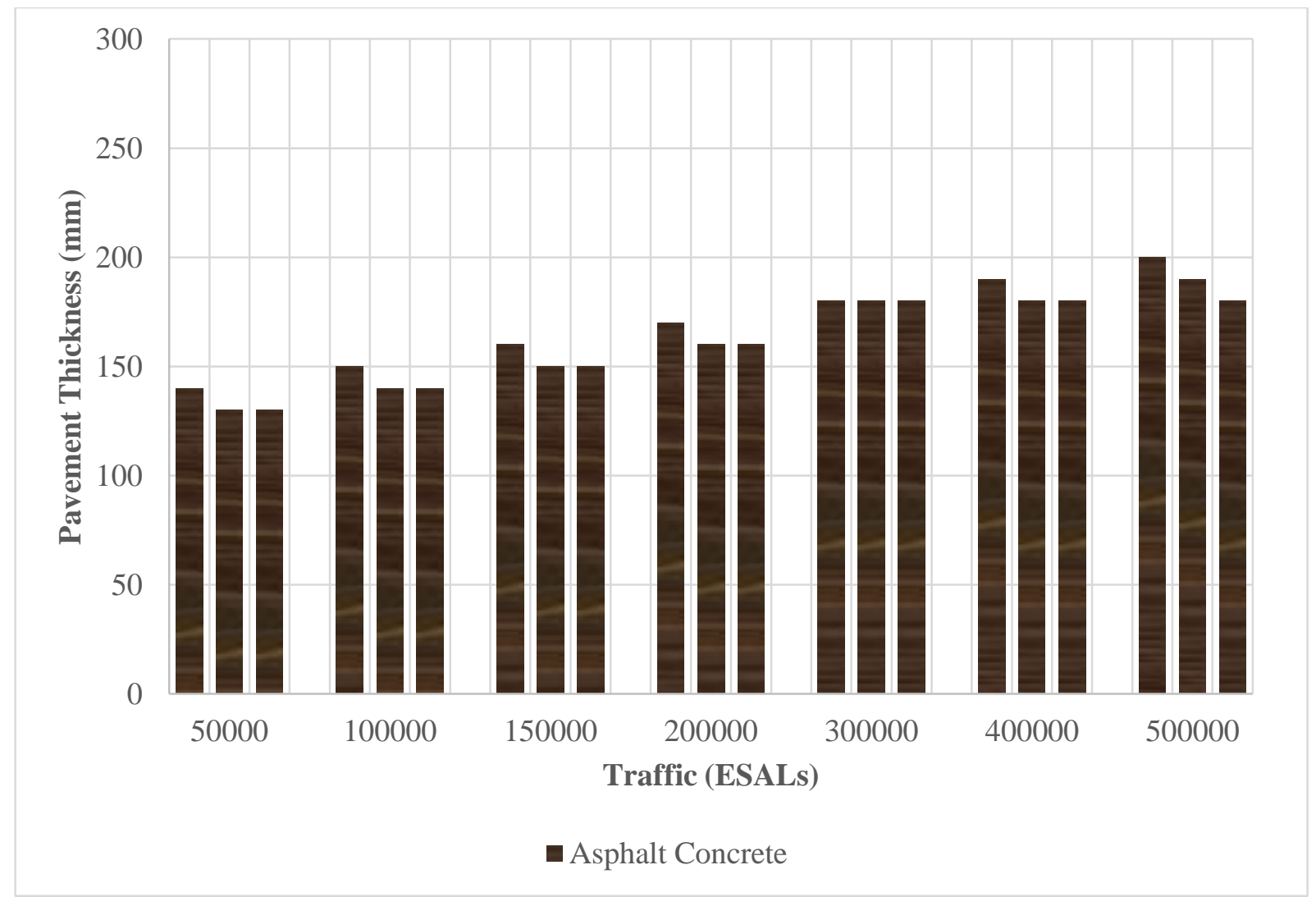

Fig. 5. Flexible pavement structures composed of AC layer.

\section{CONCLUSION}

As a result of this work, it was possible to obtain different solution alternatives in a flexible pavement structure for a region in the North of Colombia. The alternatives presented, from the modeling of the structures with mechanistic methodology, satisfy the design conditions, for a combination of characteristic factors of the roads categorized as low traffic of cargo vehicles by the Instituto Nacional de vias of Colombia. It should be noted that the proposed solution alternatives can be very useful for institutions, research groups, analysts, expert professionals and consultants in Highway Engineering who participate in projects related to soil characterization, traffic characterization and design of pavements, for roads with transits between 50,000 and 500,000 repetitions of equivalent standard axles of 8.2 tons.

\section{ACKNOWLEDGMENTS}

The authors thank the engineer Edilberto Elias Contreras Sierra for the contributions made in the development of the manuscript.

\section{REFERENCES}

[1] Sánchez F, Campagnoli S, Pavimentos asfálticos de carreteras. Guía práctica para los estudios y diseños, 1 ed., Escuela Colombiana de Ingeniería, Bogotá, 2016.

[2] Montejo A, "Ingeniería de pavimentos", 3th Edition, Universidad Católica de Colombia, Bogotá, 2016.
[3] Rondón HA, Reyes FA, Pavimentos: Materiales, construcción y diseño, 1 Ed., ECOE Ediciones, Bogotá, 2015.

[4] Instituto Nacional de Vías, Manual de diseño de pavimentos asfálticos para vías con bajos volúmenes de tránsito, Ministerio de Transporte, Bogotá, 2007.

[5] Instituto Nacional de Vías, Guía metodológica para el diseño de obras de rehabilitación de pavimentos asfálticos de Carreteras, Ministerio de Transporte, 2 ed, Bogotá, 2008.

[6] Gobernación de Sucre, Plan de Desarrollo 2016 - 2019 - Sucre progresa en Paz. http://sucre.micolombiadigital. gov.co/sites/sucre/content/files/000023/1140_plandepartamental-de-desarrollo-20162019.pdf, 2016 (accessed 28 September 2020).

[7] Comisión Económica para América Latina y el Caribe, Programa Nacional de Desarrollo Humano - Colombia. https://www.cepal.org/MDG/noticias/paginas/6/44336/ Sucre_final.pdf, 2011 (accessed 28 September 2020).

[8] ASTM D422-63(2007)e2, Standard Test Method for Particle-Size Analysis of Soils (Withdrawn 2016), ASTM International, West Conshohocken, PA, 2007, DOI: 10.1520/D0422-63R07E02.

[9] ASTM D4318-10, Standard Test Methods for Liquid Limit, Plastic Limit, and Plasticity Index of Soils, ASTM International, West Conshohocken, PA, 2010, DOI: 10.1520/D4318-10. 
International Journal of Engineering Research and Technology. ISSN 0974-3154, Volume 13, Number 11 (2020), pp. $3934-3942$

(C) International Research Publication House. https://dx.doi.org/10.37624/IJERT/13.11.2020.3934-3942

[10] ASTM D2487-10, Standard Practice for Classification of Soils for Engineering Purposes (Unified Soil Classification System), ASTM International, West Conshohocken, PA, 2010 DOI: 10.1520/D2487-10.

[11] B. M. Das, Fundamentos de ingeniería de cimentaciones, seventh ed., México, 2012.

[12] B. Yildirim, O. Gunaydin, Estimation of California bearing ratio by using soft computing systems, Expert Systems with Applications, 38 (5) (2011), pp. 63816391 https://doi.org/10.1016/j.eswa.2010.12.054.

[13] American Association of State Highway and Transportation Officials, AASHTO Guide for Design of Pavement Structures, Washington, D.C., 1993.

[14] Ministerio de Transporte, Normas y Especificaciones 2012 INVIAS, Instituto Nacional de Vías, Bogotá, D.C., 2013.

[15] Texas Department of Transportation, Subbase and subgrade performance investigation and design guidelines for concrete pavement. https://static.tti.tamu.edu/tti.tamu.edu/documents/06037-2.pdf, 2012 (accessed 28 September 2020). 